\title{
Women Empowerment in Public Higher Education Institutions in Ethiopia
}

\author{
Bezawit Girma a Ph.D. \\ Research Scholar, \\ Punjabi University, Patiala, India and lecturer at Mizan Tepi University, Tepi, Ethiopia \\ Dr. Manjit Singh \\ Professor, \\ University School of Applied Management Punjabi University, Patiala India
}

\begin{abstract}
This study explores the challenges of women empowerment in public higher education institutions in Ethiopian. To achieve the objectives mixed research approaches were applied. Multi stage sampling methods were used to identify the universities and respondents. The study was conducted in six Universities based on generation or year of establishment, namely, from first generation Addis Ababa and Mekele, from second Mizan Tepi and Dire Dawa, from third Asossa and Jijiga. 382 samples were taken from academic staffs. A structured questionnaires ware used to examine the factors affecting women empowerment. Structural equation model. Findings revealed that women empowerment is highly affected by personal, institutional and social factors.
\end{abstract}

Keywords: Ethiopia; public higher education institution; leadership; women

DOI: $10.7176 / \mathrm{DCS} / 9-4-01$

Publication date: April $30^{\text {th }} 2019$

\subsection{Introduction}

Women empowerment that refers to increasing the spiritual, political, social, educational, gender or economic strength of individuals and communities of women have been tremendously discussed in many types of research (Rown, 1997; Cubillo \& Brown, 2003; Shakeshaft, 1987) and get global recognition, in spite of the golden age of women which was ushered in by the Berlin Conference of 1995, they continue to be disadvantaged when it comes to public participation both in the public and private sectors of society. Even when they are eminently qualified and in spite of the mainstreaming of more women into public life in the last 17 years (19952016),women remain discriminated against in terms of accessing top management/leadership positions, (Broadbridge et al., 2011).

Women are denied access to both honored and utilitarian role open only to males because, in patriarchic societies, females are regarded as the inferior of the species (Strachan, Akao, Kilavanwa \& Warsal, 2010). Most continue to suffer from occupational segregation in the workplace and rarely break through the so-called glass ceiling in public life which separates them from top-level management and professional positions. Again, even the few that push through to occupy top leadership/management positions face serious challenges that can and do circumscribe their performance in these positions.

According to Sosena \& Tsehai, 2008, despite their contribution in many directions for the development of a given nation they have been considered as less productive or not. However, the study made by Munford \& Rumball, 2000 Shows that Sustainable and all around developments of a society cannot be brought without the full and unreserved participation of both woman and man in the development process.

To WB (1998), although women constitute two-thirds of the world but continue to suffer from all forms of discrimination and from the absence of adequate protection against violence. Likewise in Ethiopia Women comprises about $49.9 \%$ of the estimated Ethiopian population of 77.1 million (CSA, 2007). In Ethiopia, In spite of efforts at transforming both the country and the public service to embrace national priorities of development and economic growth, challenges persist for women across the public and private sectors. For example, while women have the potential and ability to be leaders, they often lack opportunities, resources, and support for realizing their potential (Cubillo, 1999).

Despite the progress in higher education regarding female advancement, gender discrepancies are evident based on four particularly important findings. First, women in higher education are underrepresented in leadership positions (Bonebright et al., 2012; Chin, 2011) Second, women in higher education tend to hold lower academic ranking than men (Madsen, 2012a, 2012b) Third, women are underrepresented as faculty at four-year private and public universities (NCES, 2014) and Fourth, there has not been any progress in bridging the salary gap whereby women reportedly earn less than men ( NCES, 2014; Schneider et al., 2011).

Having the above, the underrepresentation of women in academic and administrative leadership roles is a global phenomenon (Madsen, 2012a, 2012b; Pyke, 2013; Schneider et al.) and statics shows of 27 countries in the European Union, only $13 \%$ of higher education institutions are lead by women. Furthermore, female 
academics account for $16.5 \%$ of full-time university professors in the United Kingdom, and represent a little bit over 19\% of full professors at Australian universities (Morley, 2013; Schneider et al., 2011; Tessens et al., 2011).

In the Middle East and North Africa women hold 3.2\% of overall senior leadership positions (Pande \& Ford, 2011; Patel \& Buiting, 2013). Mc-Whirter, (1997)

In Ethiopia, the number of universities and colleges, vocational training center has been increasing since , 1991 (MOE, 2006 ) and showing an astonishing changes for the last 10 with the effort made by the government under growth and transformation plan one and two which have an objective of education for all( GTP1 and 2 ,2010) .Despite such astonishing changes, registered in the country in the past few year, there is lack of inclusion of women's talents, but also their beliefs in the connection between the system's abiding strength and its full utilization of women in all institution where there is no female university or college president in all universities of the country and even the number of female Lectures throughout the country is less than $0.3 \%$ (ministry of education, 2015 ). The absence of women senior leaders in higher education institutions not only causes alienation, frustration, and marginalization, but it also makes retention and recruitment of future women leaders more difficult (Cook, 2001; Konrad \& Pfeffer, 1991) which is also similar in Ethiopia those effort is made by the government and this study will intended to explore the key challenge that women faces not to come in higher education leadership position starting from department head to the president level and to do so the following research question is developed accordingly.

\section{Literature review \\ Introduction}

Leadership has been a topic of interest to historians and philosophers since ancient times but scientific studies began only in the twentieth century (Warren \& Bennis, 2009). Scholars and other writers have often more than 350 definitions of the term leadership (Warren \& Bennis, 2009). Leadership has been a complex and vague problem mostly for the reason that the nature of leadership itself is complex. A Google search of articles and books about leadership indicates, Leadership has probably been defined in many ways, like Interpersonal influence, directed through communication toward goal attainment; An act that causes others to act or respond in a shared direction; The art of influencing people by persuasion or example to follow a line of action(Andrew, 2008).

\section{Educational Leadership}

According to Tarnve (2000), educational leadership is the Continuous work of mobilizing People to believe and behave in regard to the shared vision that results in high achievement for every child. It is the ability to support people in doing inquiry about the result of their works honestly, without the fear of blame and judgment. In addition, educational leadership persuades and manages pedagogical goals and Visions undermining instructional program to promote teachers learning and development for students' improvement (Liyod, 2009).

\section{Gender-based theories}

The study was based mainly focus on the feminist theory, which explains the challenges that women are facing, including discrimination and lack of different opportunity in many aspects. Even they have equal potential regarding personal, social and institutional development. So the theories included in this study are liberal feminism, socialist feminism, and radical feminist theory.

\section{Key Barriers for women empowerments}

The key barrier for women empowerment is classified in too three namely institutional, social and personal factor.

\section{Personal factors}

Poor Self-Image or Lack of Confidence is low self-esteem, lack of confidence, motivation or aspiration is often reasons given for women's low representation in positions of educational leadership. (Shakeshaft, 1989; 1993). Some would suggest that these psychological, internal or intrinsic barriers, however, are seldom more prevalent for women than for men. On the other hand, Socialization and gender stereotyping is the other personal factor which women are limited by social expectations, parental guidance, and self-aspiration. Men are more often socialized to persevere and seek professional success while women are socialized to nurture and support others as they assume the traditional role of mother and caretaker of the home (Brown \& Irby, 2006). Also, so many literature indicate that the socialization process of females continues notions of the inferiority of the female gender.

\section{Institutional factors}

Glass ceilings and walls are systematically constructed as a consequence of cultural beliefs, behaviors, and practices (Kellerman \& Rhode, 2007). The glass ceiling metaphor emphasizes the notion that invisible and 
unseen structural patterns of gender discrimination prevent women from ascending into the most prestigious, well-paying senior leadership positions (Kellerman \& Rhode, and 2007 Berman 1999). Another institutional factor is working conditions and sex discrimination refers to the behavior of treating a person or group in an unfavorable or unfair way (Morgan, King and Robinson 1981). Women, are often the ones most likely not to react when discriminated against for fear of being harmed or further victimized which lead to the issue of women discrimination into context (Ouston 1993) says that men are still the prime barrier to women in management. Despite some progress, old-fashioned sexist attitudes are still common.

Organizational Socialization and Sex Role Stereotyping is the other factor affect women empowerment. It is the process by which new leaders become integrated into the formal and informal norms, as well as the unspoken assumptions of the work environment (Hart, 1995, Braithwaite1986). Because traditional stereotypes cast women as socially incongruent as leaders, they face greater challenges becoming integrated into the organization attributed women's failure to advance to upper-level leadership positions in schools to oversaturation with the cultural message of female inferiority within male systems (Hart, 1995, Braithwaite1986).

The decisions made about hiring, promotions and paying women leaders is strongly influenced by its culture and the gender stereotypes that underlie it (Howard and Wellins 2009). Because of weak assumptions that consider women have less career ambition and diminished loyalty to their employers because of their more significant caring and household responsibilities (Howard and Wellins, 2009 and Piterman, 2008).

\section{Social factors}

Work and Family Conflict is a common reason for women's underrepresentation in leadership positions centers on work and family conflict (Kamler and Shakeshaft, 1999). Kellerman \& Rhode, have pointed out how some women are simply rejecting leadership roles for a greater focus on family, a decision that inherently affects their long-term career paths. Also, they explained the timing of a woman's choice to have children can often delay the completion of their undergraduate or graduate education, which ultimately leads to higher career advancement. Gendered Cultural and Social Values is the other factor which cultural and social assumption that women are less strong than men and therefore cannot hold managerial positions is common in many developing countries (Calvert and Calvert, 1996). The double standard in describing female characteristics which consider Men might be called absentminded, but women are scatterbrained; men might be described as intellectually curious, but women are nosy; men are planners, but women are schemers (Write, 2001).

Male Dominated Power Structure the main barrier for women empowerment because men in senior positions will hire those candidates who most resemble themselves, thereby reproducing male dominance within educational administration (Oplatka \& Hertz-Lararowitz, 2006) and also Writing in the American context, Shakeshaft (1989), has recognized the ways in which male manager did not want to work with females as they saw them as a threat.

The last but not the list the barrier for women empowerment is lack to access resources, lack of career advice, resources, mentoring, and socialization of women in academic leadership positions (Paludi, 2008).

\section{Materials and Methods \\ Description of the study area}

This research was conducted in six Ethiopian public universities, namly Addis Ababa, Mekelle, Mizan-Tepi, Dire Dawa, Asossa and Jijiga University. These universities are selected based on generation or year of establishment. The study is a descriptive research design which focuses on the challenges of women empowerment in Ethiopian public universities.

\subsection{Sample size and sampling technique}

A multi-stage sampling was used to select study area and respondents. Cluster sampling was employed for selecting the Universities followed by systematic random sampling techniques and Proportional sample allocation techniques for each selected university. To calculate the sample the following formula from the given population by taking into accounts $0.05(5 \%)$ standard error or significant level were applied.

$$
S s=\frac{Z^{2}(P)(1-P)}{E^{2}}
$$

The total sample size was 382 from the total population of 9336 .

\subsection{Data Collection Instruments}

Questionnaires were prepared in five-point Likert's scale and designed to female and male respondents which are lecturers in selected university. The items were targets on the three main factors i.e. social, institutional and personal factors that are universally considered as a major element that affects women empowerment in all sectors. 


\subsection{Method of Analysis}

Factor analysis together with structural equation modeling was used to test and identify the variables impact on one another on women empowerment. Confirmatory factor analysis the researcher used 21.0 version SPSS software. This software has been widely used by researchers as a data analysis technique (Zikmund 2003).

\section{Analysis and discussion \\ Factor Analysis}

With the goal of this research a primary extraction technique factor analysis (FA) which is widely used in the research filed has been adopted for the validity test. FA used to study the pattern of relationship among dependent variable and discover if the observed variable can be explained largely by key factor. It is multivariate technique that reflects the structure of the concept that indicates which of the factor the structure of the concept that which of the item is most appropriate for each dimension (sekaran, 2003). There are basically two purposes for FA. One is to reduce the number of variables and another one is to detect structure in relationships between variables. The output of FA concentrates on variables with high commonalities is the variance that is distributed among factors and is less than the total variance in the set of observed variables (Tabachnick and Fidell, 2007) Therefore, FA could examine whether a questionnaire was designed to measure the researchers assume the structure of the research theory. For this study, the purpose of FA is to measure whether the questionnaire fit the component factors or not detect the structure of the theoretical model. It is the necessary condition for the SEM process. In order to verify the suitability of the data for FA, some preconditions shall be achieved before the further test. The main steps for FA are discussed below (pallant, 2005)

\section{Preconditions for FA}

There are two main issues to consider in determining the suitability of data for FA. 1) Many scholars recommend the larger the sample size, the better (pallant, 2005). However, in general, there should be at least 150 cases. In this study, 382 Cases have been collected. Secondly the factorability of the correlation matrix this assumption requires that within the correlation matrix at least some of coefficient $r$ is greater than 0.3 . Furthermore two other statistical measures can also help to assess the factorability of the data, which are Bartlett's test of sphericity; is a statistical test for the overall significance of all correlations with a correlation matrix and the Kaiser-Meyer -0lkin (KMO ) measure which is also known as the eigenvalue rule (pallant,2005; Hair et al, 1998) also Norman and Streiner (p 197) quote Tabachnick \& Fidell (2001) saying that if there are few correlations above 0.3 it is a waste of time carrying on with the analysis, clearly we do not have that problem.

\begin{tabular}{|l|l|r|}
\hline \multicolumn{2}{|c|}{ KMO and Bartlett's Test } \\
\hline Kaiser-Meyer-Olkin Measure of Sampling Adequacy. & .894 \\
\hline \multirow{2}{*}{ Bartlett's Test of Sphericity } & Approx. Chi-Square & 15223.527 \\
\cline { 2 - 3 } & df & 1081 \\
\cline { 2 - 3 } & Sig. & .000 \\
\hline
\end{tabular}

For the KMO statistic Kaiser (1974) recommends a bare minimum of .5 and that values between .5 and .7 are mediocre, values between .7 and .8 are good, Values between .8 and .9 are great and Values above .9 are Superb (Hutcheson \& Sofroniou, 1999). For these Data, the Value is .894, which falls into the range of being good, so it should be confident that the sample size is Adequate for factor analysis.

\section{Factor Loading}

It refers to the degree of correlation between variables and factors and in general, the requirements for this value should be no less than 0.3 (pallant, 2005). Some scholars believe that when the variables have a loading greater than 0.4 it is considered to be relatively significant. When loading is greater than 0.5 , it is considered to be very significant. When lodgings are greater than 0.6 , it indicates that the variables are highly correlated with each other (Zeng and Huang, 2005). Comrey \& Lee (1992). In this research, a very screened part of the FA is presented accordingly. 
Table .....Factor analysis output

Factor analysis output

Personal factor (F1)

A perceived personal thought on Lack of support system

Lack of family support

Conflicts with family responsibility

Natural problems with being a woman ( Giving birth)

Unwillingness to assume the position

Lack of ambition

Lack of emotional stability

Psychological glass ceiling

Poor self-image

Socialization and gender structure

Listening

Limiting the discussion to relevant points

Skill for motivating others

Institutional Factor (2)

Women have the objectivity required to evaluate organizational situations properly

Challenging work is more important to men than women

Men and women should be given equal opportunity for participation in leadership responsibilities

Women have the capability to acquire the necessary skills to be successful leaders

Perceived thought women leaders are less capable of contributing to an organization's overall goals

It is not acceptable for women to assume leadership roles as often as men

Low academic qualification

Inadequate job knowledge/competence

Lack of a role model

Unclear appointment criteria

Patriarchal culture in academia

Nepotism (based on Political Affiliation ethnicity,.etc)

Stereotyping (Associating leadership with men women)

SOCIAL FACTOR (F3)

Women are not ambitious enough to be successful in the business world

Women cannot be assertive in organizational situations that demand it

Women possess self-confidence required of a good leader

Women are not competitive enough to be successful in the business world

Women cannot be aggressive in organizational situations that demand it

Sexual harassment

Discrimination against women

Perception On Women Leadership Ability (F4)

I perceive that women's are under-represented

women's are challenged in the intuitions by the academic staff

women's are challenged in intuitions by the immediate boss

\begin{tabular}{|c|c|c|c|c|}
\hline 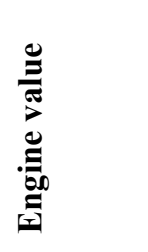 & 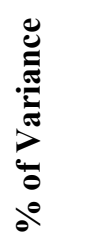 & 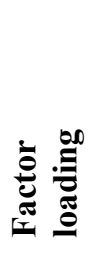 & 苑 & 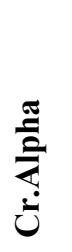 \\
\hline \multirow[t]{14}{*}{14.99677} & 31.908 & & & .924 \\
\hline & & .587 & .454 & \\
\hline & & .569 & .500 & \\
\hline & & .596 & .603 & \\
\hline & & .730 & .460 & \\
\hline & & .598 & .578 & \\
\hline & & .715 & .656 & \\
\hline & & .769 & .698 & \\
\hline & & .797 & .572 & \\
\hline & & .729 & .627 & \\
\hline & & .736 & .509 & \\
\hline & & .584 & .582 & \\
\hline & & .699 & .454 & \\
\hline & & .565 & .500 & \\
\hline \multirow[t]{14}{*}{4.654} & 9.903 & & & .930 \\
\hline & & .663 & .620 & \\
\hline & & .647 & .566 & \\
\hline & & .667 & .579 & \\
\hline & & .647 & .585 & \\
\hline & & .697 & .628 & \\
\hline & & .535 & .495 & \\
\hline & & .631 & .288 & \\
\hline & & .743 & .351 & \\
\hline & & .650 & .230 & \\
\hline & & .711 & .328 & \\
\hline & & .705 & .682 & \\
\hline & & .732 & .688 & \\
\hline & & .712 & .718 & \\
\hline \multirow[t]{8}{*}{3.563} & 7.582 & & & .944 \\
\hline & & .770 & .730 & \\
\hline & & .756 & .779 & \\
\hline & & .790 & .768 & \\
\hline & & .803 & .790 & \\
\hline & & .805 & .753 & \\
\hline & & .738 & .652 & \\
\hline & & .700 & .590 & \\
\hline \multirow[t]{4}{*}{2.719} & 5.786 & & & .892 \\
\hline & & .510 & .328 & \\
\hline & & .803 & .682 & \\
\hline & & .820 & .688 & \\
\hline
\end{tabular}




\begin{tabular}{|c|c|c|c|c|c|}
\hline \multicolumn{6}{|c|}{ Table .....Factor analysis output } \\
\hline Factor analysis output & 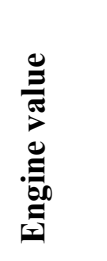 & 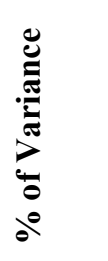 & 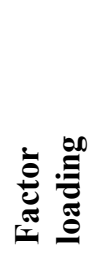 & 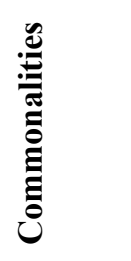 & $\frac{\pi}{\grave{2}}$ \\
\hline Women are challenged by administration staffs & & & .835 & .718 & \\
\hline I perceive that women's are under-represented & & & .822 & .695 & \\
\hline $\begin{array}{l}\text { i believe that social issues facing women's affects women } \\
\text { empowerment interest }\end{array}$ & & & .815 & .682 & \\
\hline Women Empowerment Challenges(F5) & 2.601 & 5.535 & & & .913 \\
\hline $\begin{array}{l}\text { I believe that the above existence or not existence affect } \\
\text { women's interest to come to power }\end{array}$ & & & .834 & .820 & \\
\hline $\begin{array}{l}\text { I believe that social issues facing women affect women } \\
\text { empowerment interest }\end{array}$ & & & .833 & .847 & \\
\hline $\begin{array}{l}\text { I believe that personal issues facing affects women } \\
\text { empowerment interest }\end{array}$ & & & .825 & .792 & \\
\hline $\begin{array}{l}\text { I believe that the organizational issues facing women affect } \\
\text { women empowerment interest }\end{array}$ & & & .826 & .786 & \\
\hline \multicolumn{6}{|l|}{$\begin{array}{l}\text { Extraction Method: Principal Component Analysis. } \\
\text { Rotation Method: Varimax with Kaiser Normalization. }\end{array}$} \\
\hline \multicolumn{6}{|l|}{ a. Rotation converged in 5 iterations. } \\
\hline \multicolumn{6}{|c|}{$\begin{array}{l}\text { SPSS output three lists the Eigenvalues associated with each linear component before extraction, after } \\
\text { extraction, and after rotation. Before extraction, SPSS has identified a linear component within the data set the } \\
\text { Eigenvalues associated with each factor represent the variance explained by the particular linear component and } \\
\text { SPSS also display the Eigenvalue in terms of percentage of variance having this The Initial Eigenvalues - first } 5 \\
\text { factors are meaningful as they have Eigenvalues }>1 \text {. Factors } 1,23,4 \text { and } 5 \text { explain, } 31.908 \%, 9.903 \% \text {, and } \\
7.582 \%, 5.786 \% \text { and } 5.535 \% \text { of the variance respectively. The model explained } 60 \% \text { of the variance. } \\
\text { The Extraction Sums of Squared Loadings which have the effect of optimizing the factor structure provides } \\
\text { similar information by equalizing the relative importance of the five factors based only on the extracted factors } \\
\text { and as shown in the data set before rotation factor one accounted for considerably more variance there remaining } \\
\text { four ( } 37.855 \% \text { compare to } 14,12.998,10.283 \text { and } 6.938 \% \text { respectively )however after rotation it accounts for } \\
\text { only } 29.307 \text { of variance compared to } 16.682,14,135,11.511 \text { and } 10.460 \% \text { respectively this leads us to the } \\
\text { conclusion that a five-factor solution will probably be adequate }\end{array}$} \\
\hline
\end{tabular}

\section{Factor Extraction}

It involves determining the smallest number of factors that can be used to best represent the interrelation among the set of variables (pallant,2005) criteria used for extraction procedure such as principal component, maximum likelihood factoring or alpha factoring differ from each other but have little difference in solution. the principal component method which is a technique to estimate factor loading for the population by calculating loading that maximizes the probability of sampling used in the study (Hair et al. 1998). Although, there are a number of techniques that can be used to assist in the factor retaining decision processes such as Kaiser criterion, score plot and parallel analysis, many scholars recommend that it is up to the researcher to determine the number of factors that he/she consider to best describe the underlining relationship between the variables (Pallant,2005). In addition to this, Tabachnich and Fidell (2001) consider that a researcher should take a different number of factors for experimenting to find a solution that fits their theory test.

Commonalities can be thought of as the R2 for each of the variables that have been included in the analysis using the factors as initial variances and the item as a difference in variance. It represents the proportion of variance of each item that is explained by the factors. This is calculated of the initial solution and then after extraction. These are reported in the Initial and Extraction Initial communalities are estimates of the variance in each variable accounted for by all components or factors. Extraction communalities are estimates of the variance in each variable accounted for by the factors (or components) in the factor solution. In this study, A small value was suppressed with .5 threshold and items were extracted based on the result in all five-factor a minimum pint was .5 and maximum .8 were registered which is good to conduct any further analysis like SEM. ( see appendix and table......) 


\section{Reliability}

Reliability is an assessment of the degree of consistency between multiple measurements of a construct or variable (Hair Jr. et al., 2006, p. 137). Reliability is concerned with estimates of the degree to which a measurement is free of random or unstable error (Cooper \& Schindler, 2008). A construct can be said reliable if the answer of the respondent towards the question is consistent or stable over time. The first indicator, the testretest, is assessed by administering the same scale of measurement to the same respondents on two various occasions, and computing the correlation between the two scores obtained (Zikmund et al., 2010).

The second indicator, the internal consistency, is the degree to which the items constituting the scale are all measuring the same underlying attribute (Zikmund et al., 2010). The most common indicator used for computing the internal consistency is coefficient alpha (Pallant, 2010). According to Zikmundet al. (2010) coefficient alpha ranges from 0 (no internal consistency) to 1 (complete consistency). Scales with coefficient alpha between 0.8 and 0.95 are considered to have very good quality, scales with coefficient alpha between 0.7 and 0.8 are considered to have good reliability, and coefficient alpha between 0.6 and 0.7 indicates fair reliability (Zikmund et al., 2010). For this study, a Cronbaches Alpha score of .70 or higher is considered adequate when determining reliability (Fraenkel \& Wallen, 2007). Thus, based on the conceptual model of the study factor analysis can be retained for each construct of the modal.

Rules of thumb about Cronbach's alpha (a) coefficient size

\begin{tabular}{|l|l|}
\hline Alpha Coefficient Range & Strength of Association \\
\hline$<0.6$ & Poor \\
\hline 0.6 to $<0.7$ & Moderate \\
\hline 0.7 to $<0.8$ & Good \\
\hline 0.8 to $<0.9$ & Very Good \\
\hline$>0.9$ & Excellent \\
\hline
\end{tabular}

Source: Hair Jr. et al. (2007, p. 244)

All the result shows, form the above-screened data all the factors have an Alpha Coefficient Range between .8 to .99 which falls under the category of very good and excellent association range. (See table.......... And appendix ............)

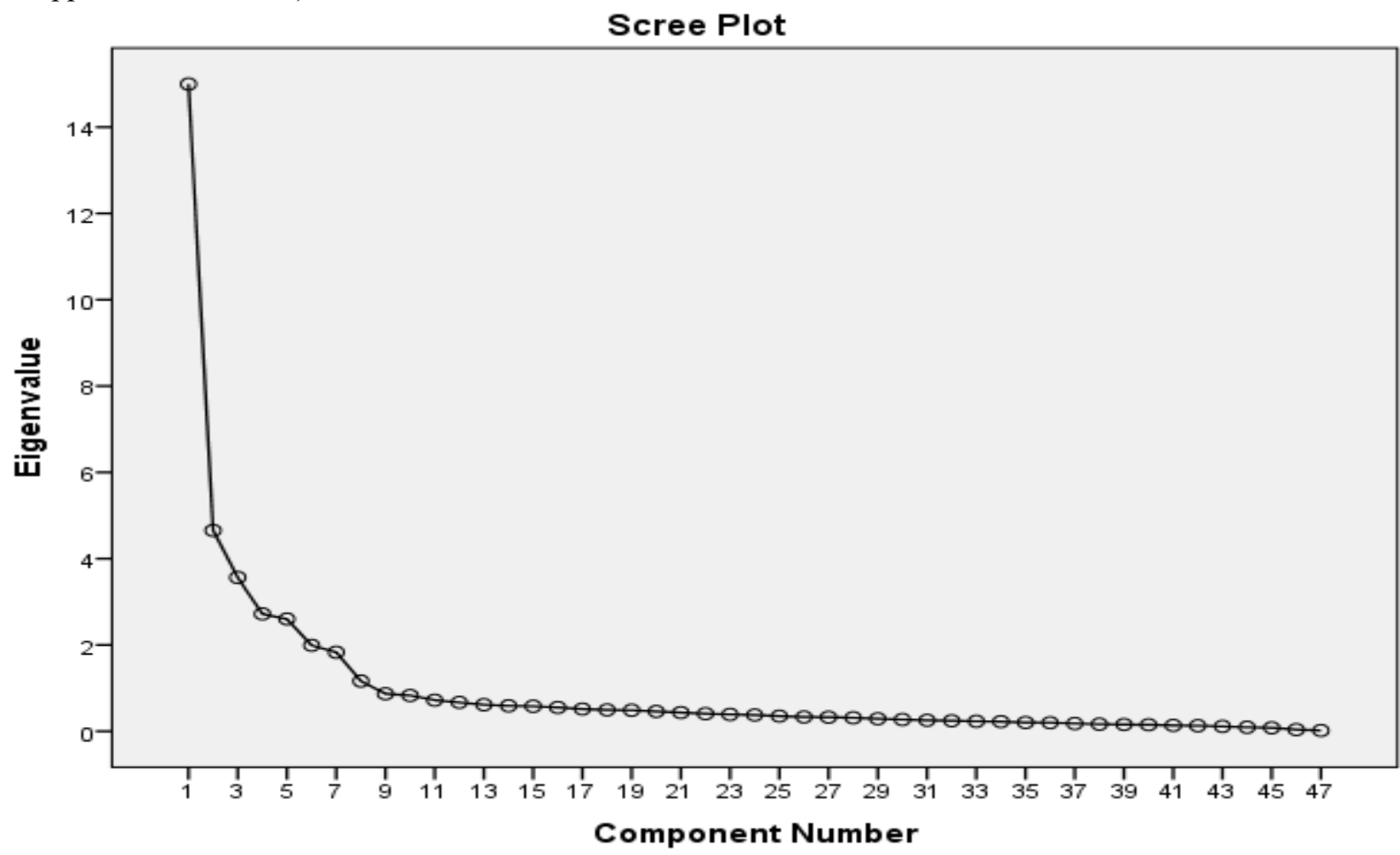

\section{Source: - Own Survey 2018}

For the application of challenges of women experiment data, this plot shows also show that there are five relatively high (factors 1, 2, 3, 4 and 5) Eigenvalues to gather the five of them cover more than $60 \%$. Retain factors that are above the 'bend' - the point at which the curve of decreasing Eigenvalues change from a steep line to a flat gradual slope so it is better to retain only the first five components. 


\section{Hypostasis testing using structural equation modeling}

\section{Structural equation modeling}

Table .... Contains fit indices for the proposed both models based on a maximum likelihood CFA analysis of the covariance matrix for the six latent variables. The Chi-Square / Degree of Freedom $(\chi 2 / \mathrm{df})$ for the two model less than the recommended value of 5 (Loo \& Thorpe, 2000); the GFI, NFI, RFI, IFI, TLI and CFI for both models exceeded the recommended value of 0.9 (J. F. Hair, et al., 2006).

Model for challenges of women empowerment in Ethiopia higher education

\begin{tabular}{|l|l|}
\hline List of Measurement & Measurement Item \\
\hline CMIN/DF & $1.813(3)$ \\
\hline P & .178 \\
\hline Chi square & 1.813 \\
\hline RMR & .211 \\
\hline GFI & .998 \\
\hline NFI & .998 \\
\hline RFI & .983 \\
\hline TLI & .992 \\
\hline CFI & .999 \\
\hline RMSEA & .046 \\
\hline HOELTER .05 & 808 \\
\hline HOELTER.01 & 1394 \\
\hline \hline
\end{tabular}

The RMSEA for the models were less than the recommended value of 0.08 (Browne \& Cudeck, 1993). It can be concluded that the analysis using modification indices of both models had a good fit from a practical standpoint. These fit indices were higher than the corresponding fit indices with empirical data.

Estimate: - maximum likelihood estimate

\begin{tabular}{|l|l|l|r|l|l|l|r|r|c|}
\hline & & Estimate & St. T E. & D. E & I.E & C.R & P & \\
\hline leadership & $<---$ & Social factor & .047 & .047 & .030 & .000 & .414 & $* * *$ & Confirmed \\
\hline leadership & $<---$ & Organizational & .198 & .198 & .332 & .000 & 2.000 & $* * *$ & Confirmed \\
\hline leaderships & $<---$ & Personal & .091 & .091 & .048 & .017 & 1.192 & $* * *$ & Confirmed \\
\hline challenge & $<---$ & Leadership & .313 & .313 & .353 & .000 & 6.784 & $* * *$ & Confirmed \\
\hline challenge & $<---$ & Organizational & .065 & .127 & .122 & .117 & .718 & $* * *$ & Confirmed \\
\hline challenge & $<---$ & Social factor & .271 & .286 & .194 & .011 & 3.027 & $* * *$ & Confirmed \\
\hline
\end{tabular}

Figure ............shows the structural equation model of factor affecting women empowerment after computes modification Indices (MI) for each group. The results indicated that there were significant influences between the leadership, personal, social and organizational factors. Beside, organizational and social factor is the major factor that affects women empowerment in Ethiopia higher public institution. Also composite reliability and Mahalanobis d-squared test that shows normality and reliability and normality of the data is below the threshold that ensures the proposed hypothesis is accepted accordingly.

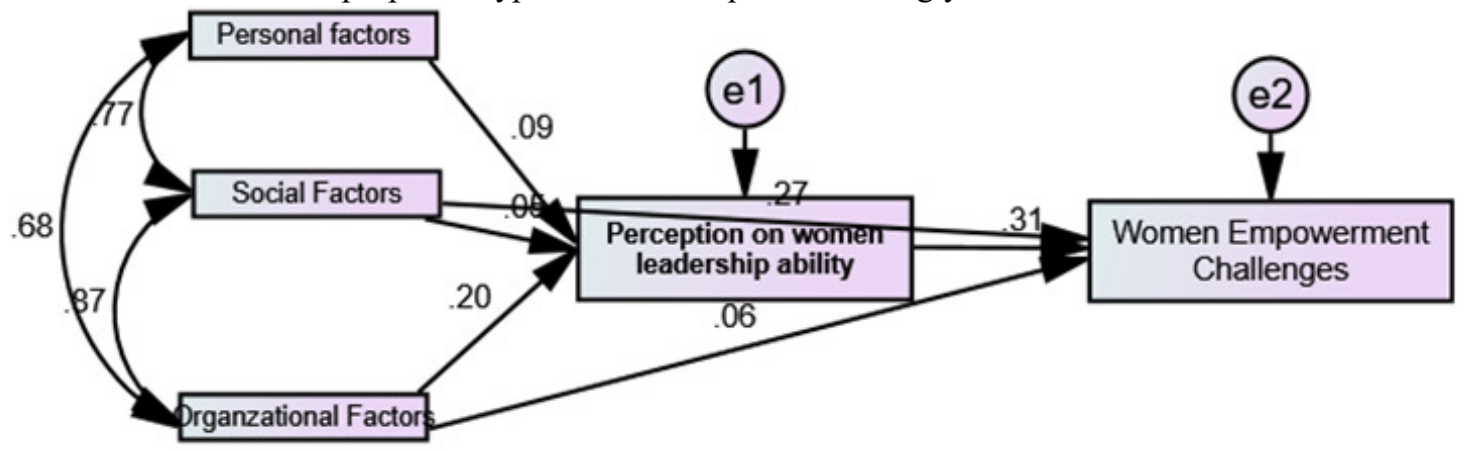

Fig 2:- Factor that affects women empowerment

Conclusion and recommendation

In overall, this study revealed that women who are working in a higher public institution in Ethiopia highly affected by personal, institutional and social factors. Lack of confidence or poor self-image, psychological glass ceiling, and socialization process of females that considers as Personal factors significantly affect women empowerment in public higher education institution in Ethiopia meanwhile previous studies were done in Turkey, Pakistan, Iran, UEA, Egypt, and Uganda shows personal factors matters on women empowerment 
interest in public higher education institution. (Hammoud, R 1991; Hussain, F 1984; Chitins, 1990). This shows the finding of the current study is consistence with previous researches done in different countries. Therefore, the problems of women empowerment vs personal factor are common in most developing sub-Sahara, Middle East, and Islamic countries. Moreover, masculine countries have shown challenges on women empowerment (Oplatka \& Hertz-Lararowitz, 2006; Sczesny, 2003; Hoyt, 2005).

Organizational glass ceiling, Working conditions and sex discrimination, Organizational socialization and sex-role stereotyping and human resources practices and hiring process are institutional factors those tremendously affected women empowerment in public higher education institution in Ethiopia. Also, other researches made in Australia, United Kingdom, and European Union illustrated institutional factors have a big negative impact on women empowerment in public higher education institution ( Morley, 2013; Schneider et al., 2011; Tessens et al., 2011 and Pyke, 2013). Therefore, this implied that the institutional barriers towards women empowerment is also visible in developed countries as observed in the above.

Also, the study revealed that work and family conflict, gendered cultural and social values, the relationship dynamics, male-dominated power structure, gender stereotypes and access to resources extremely hinder women empowerment in higher public education institution as social factors.

Based on the above conclusions the following recommendation is provided. It has been clearly shown that the gap has been seen in women empowerment in Ethiopia public higher education institution. Therefore the government shall take responsibility to empower women's by building their capacity, and creating awareness within the societies, making rules, regulation and strategies at university and community level. Even the quota for women leader is not fair enough because as they are half of the population and if they are will trained and have skill and ability the policy should be $50 \%$ of the university position should be filled by women leaders. Based on this other implementer needed to train and develop their skill regarding women, stereotypes and organizational glassing ceiling should be avoided.

The society shall give great emphasis for women they have to teach, support and need to understand their problem. Because home is the first school for them. So they have to teach their children with the spirit of woman can do anything. So they will break the personal glass ceiling and they will be confident regarding any situation. Consequently the overall community should aware of how women are magnificent if they treat them fairly and their spouse should share their burden at home including taking care of their families.

Universities are the other responsible body to guide, train and empower women regardless the policy made by the government. Moreover, there should be internal policy derived from the strategic policy which helps them to empower women by creating a comfortable environment because women have double responsibilities. So there should be daycare, accesses to telephone....in University. The empowerment process should be through development and capacity building not for the sack of report. Motivating and encouraging woman role models in the university to persuade others.

Women should make ready themselves to cope up with any change that happening around them they should be open-minded, ready to learn and to take the opportunity for better tomorrow. They are supposed to break the glass ceiling that surrounded them and shall tell themselves they can do anything.

\section{Reference}

Alomair, M. O. (2015). Female leadership capacity and effectiveness: A critical analysis of the literature on higher education in Saudi Arabia. International Journal of Higher Education, 4(4), 81.

Bennis, W. (2009). Crises reveal the quality of leadership. Leader to Leader, 2009(54), 27-31.

Bergeron, S. (2003). The post-Washington consensus and economic representations of women in development at the World Bank. International Feminist Journal of Politics, 5(3), 397-419.

Broadbridge, A., \& Simpson, R. (2011). 25 years on: reflecting on the past and looking to the future in gender and management research. British Journal of Management, 22(3), 470-483.

Brunner, C. C. (Ed.). (1999). Sacred dreams: Women and the superintendency. SUNY Press.

Celikten, M. (2005). A perspective on women principals in Turkey. International Journal of Leadership in Education, 8(3), 207-221.

Chen, X. (2013). STEM Attrition: College Students' Paths into and out of STEM Fields. Statistical Analysis Report. NCES 2014-001. National Center for Education Statistics.

Chin, J. L. (2011). Women and Leadership: Transforming Visions and Current Contexts. In Forum on Public Policy Online (Vol. 2011, No. 2). Oxford Round Table. 406 West Florida Avenue, Urbana, IL 61801.

Cook, A., \& Glass, C. (2011). Leadership change and shareholder value: How markets react to the appointments of women. Human Resource Management, 50(4), 501-519.

Crosby-Hillier, K. (2012). Women and educational leadership: exploring the experiences of current and aspiring female educational administrators.

CSA, C. (2007). The 2007 population and housing census of Ethiopia.

Cubillo, L., \& Brown, M. (2003). Women into educational leadership and management: international 
differences?. Journal of educational Administration, 41(3), 278-291.

Djupe, P. A. (2014). The effects of descriptive associational leadership on civic engagement: The case of clergy and gender in protestant denominations. Journal for the Scientific Study of Religion, 53(3), 497-514.

Embry, A., Padgett, M. Y., \& Caldwell, C. B. (2008). Can leaders step outside of the gender box? An examination of leadership and gender role stereotypes. Journal of Leadership \& Organizational Studies, 15(1), 30-45.

Fitzgerald, T. (2003). Changing the deafening silence of indigenous women's voices in educational leadership. Journal of Educational Administration, 41(1), 9-23.

Girma, M. P. (2010). Teaching, Learning and Assessment Practices in Ethiopian Higher Education Institutions: The Quality Aspect in Focus.

Gobena, L. (2014). Major factors that affect female teachers' participation in school leadership: The case of public primary schools in Jimma Town (Doctoral dissertation, Jimma University).

Grogan, M., \& Shakeshaft, C. (2010). Women and educational leadership (Vol. 10). John Wiley \& Sons.

Hammoud, R. S. (1993). Bahrain: the role of women in higher education management in the Arab region. Women in higher education management, 107-122.

Hart, A. W. (1995). Women ascending to leadership: The organizational socialization of principals. Women leading in education, 105-124.

Hora, E. A. (2014). Factors that affect women participation in leadership and decision making position.

Howard, A., \& Wellins, R. (2009). Holding women back: Troubling discoveries and best practices for helping female leaders succeed. Global leadership forecast 2008/2009.

Hoyt, C. L. (2005). The role of leadership efficacy and stereotype activation in women's identification with leadership. Journal of Leadership \& Organizational Studies, 11(4), 2-14.

Hussain, F. (1984). Introduction: The ideal and contextual realities of Muslim women. Muslim women, 1-7.

Kellerman, B., Rhode, D. L., \& O'Connor, S. D. (2007). Women and leadership: The state of play and strategies for change (Vol. 141). Jossey-Bass.

Lloyd-Jones, B. (2009). Implications of race and gender in higher education administration: An African American woman's perspective. Advances in developing human resources, 11(5), 606-618.

Madsen, S. R. (2012). Women and leadership in higher education: Current realities, challenges, and future directions. Advances in Developing Human Resources, 14(2), 131-139.

Madsen, S. R. (2012). Women and leadership in higher education: Learning and advancement in leadership programs. Advances in Developing Human Resources, 14(1), 3-10.

Morley, L. (2013). The rules of the game: Women and the leaderist turn in higher education. Gender and education, 25(1), 116-131.

Munford, R., \& Rumball, S. (2000). Women in university power structures. Women, Power, and the Academy: From Rhetoric to Reality, 92-98.

Oplatka, I. (2006). Women in educational administration within developing countries: Towards a new international research agenda. Journal of Educational Administration, 44(6), 604-624.

Ouston, J. A. N. E. T. (1993). women as managers. Women in education management, 1-16.

Paludi, M. A. (Ed.). (2008). the psychology of women at work: Challenges and solutions for our female workforce (Vol. 2). ABC-CLIO.

Pande, R., \& Ford, D. (2012). Gender quotas and female leadership.

Perlini, A. H., Marcello, A., Hansen, S. D., \& Pudney, W. (2001). The Effects Of Male Age And Physical Appearance On Evalu A Tions Of Attractivenes, Social Desirability And Resourcefulness. Social Behavior and Personality: an international journal, 29(3), 277-287.

Piterman, H. (2008). The leadership challenge: Women in management. Committee for Economic Development of Australia, Melbourne.

Pyke, J. (2013). Women, choice and promotion or why women are still a minority in the professoriate. Journal of Higher Education Policy and Management, 35(4), 444-454.

Schneider, M. C., \& Bos, A. L. (2014). Measuring stereotypes of female politicians. Political Psychology, 35(2), 245-266.

Sczesny, S. (2003). The perception of leadership competence by female and male leaders. Zeitschrift fur Sozialpsychologie, 34(3), 133-145.

Shakeshaft, C. (1987). Organizational Theory and Women: Where Are We?.

Shakeshaft, C. (1989). Women in educational administration. Sage Publications, Corwin Press, 2455 Teller Road, Newbury Park, CA 91320.

Shakeshaft, C., Brown, G., Irby, B. J., Grogan, M., \& Ballenger, J. (2007). Increasing gender equity in educational leadership. Handbook for achieving gender equity through education, 2, 103-129.

Shettar, D., \& Rajeshwari, M. (2015). A study on issues and challenges of women empowerment in India.

Stelter, N. Z. (2002). Gender differences in leadership: Current social issues and future organizational 
implications. Journal of Leadership Studies, 8(4), 88-99.

Strachan, J., Akao, S., Kilavanwa, B., \& Warsal, D. (2010). You have to be a servant of all: Melanesian women's educational leadership experiences. School leadership and management, 30(1), 65-76.

Tessens, L., White, K., \& Web, C. (2011). Senior women in higher education institutions: perceived development needs and support. Journal of Higher Education Policy and Management, 33(6), 653-665.

Watt, D. (Ed.). (1997). Medieval women in their communities. University of Toronto Press. 